\title{
The Structural Analysis of Symbols in the Ashurayi Literature
}

\author{
Marziyeh Mohammadzadeh
}

PhD in Philology of National University of Tajikistan, Scientist of Islam World, Iran

Received: 24 October 2018, Revised: 05 December 2018, Accepted: 20 December 2018

\begin{abstract}
The tragedy of Imam Husayn martyrdom (the son of Imam Ali (pbuh), the grandson of The Prophet, 10 Muharram in the year 61 AH (in AHc: October 9, and in AHt: October 10, 680 CE) occurred in Karbala plain, beside Forat river in Iraq. Yazid, the son of Moavie, the second Umayyad Caliphate sent his messengers to pay pledge/kneel and he didn't accept because of his deviation from Islam religion. The respected personality of Imam Husayn among the Muslims, the depth of the tragedy and telling the details of the event by the survivors namely his sister and son caused grief in important cities including Mecca, Medina and Kuffe and it was developed in all Islamic countries as the respect to this tragedy was prevalent in the Muslim culture namely Shia people. Shia people all over the world mourn the head of the martyrs to keep the sad event for ever and they applied some symbols in their mourning and they are held over the time in the form of special rites during Moharam and Safar. The frequency of the symbols indicates the deep effect of Ashura tragedy in Shia culture. The symbols have different names in different cultures of Islamic countries. The reasons and the method of the application of mourning symbols in various Islamic countries namely the pathology of the symbols in terms of negative effects on the principle of the aim of Imam Husayn are the main objective of the present study.
\end{abstract}

Keywords: Ashura, Imam Husayn (pbuh), Mourning, Symbol.

\section{Introduction}

Symbol: Symbol indicates the existence of other independent object except the symbol itself including the people, symbols, words and numbers. Most of the symbols are common in sciences as abbreviations in chemistry and math. Symbol is common in religion for a long time as complex components and they are considered important concepts in communication sociology. According to sociology, the symbols are objective manifestations displaying the known meanings by all or most of the people in the society .

Symbolism: Symbolism is the art of using the symbols, for example by considering symbolic meaning for the objects or expressing invisible creatures by showing them as visible. There are considerable symbolism examples in religion.

There is a kind of symbolism in Islamic rites and Sufie and Islamic scholars 
considered symbolic meanings for some of the rites or all of them. For example, Ibn Arabi considered raising hand in prayer as confessing to be obedient as he is empty hand before Allah and there is no wealth or power. Qazali considered wearing Ahram (Hij) attires as a symbol of the consideration of human being to the fact that during visiting Allah as in tomb, human being has nothing but Kafan.

\section{Mourning}

Definition: Literally, mourning means crying and grief for a dead person. The patience against the problems and tolerating the loss of the relatives and friends during mourning. The first symbol of mourning after the death of a person is wearing mourning attires that is black, gray and blue.

Background: Ferdosi in Shahname said: People put on black attires at the death of Iraj, the son of Fereidoon .

Ibn Batute in his trip diary said: In Seljukian era, at the death of people, the mourners were wearing the cloth as upside down and there was nothing on their head.

Henry Rene, French tourist explained about the mourning and introduction of the mourners in Islamic art history book. For example, if the dead person was young, all his belongings were destroyed. In some regions of Islam world, they prevented the presence of women in mourning because they were crying more. Mecca women were crying from night to morning in Jaheliat tradition after some of the pagans were killed in Badr war and while they were wearing black, they were informed of the death.

Making the cloth black by coal by the female mourners was common in the past.

One of the old rites in mourning was "Barat tradition". The Muslims in Iran, central Asia, Egypt, Andoles, Iraq and
Afghanistan in the middle centuries for the memorial of the loss of their relatives, they had "Leilat Al-Barat" on 14th of Shaaban (Islamic calendar) each year. The day was called Barat as they believed that their dead relatives were at the mercy of Allah and they are released of the torture of Allah at this night.

The Prophet (pbuh) by mourning Hamze and Jafar Ibn Abitaleb and most of the followers' martyrdom was sad and he cried and even encouraged the followers for mourning for them.

The positive and historical effect of the mourning by The Prophet caused that since then until Karbala event and the martyrdom of Imam Husayn, before any mourning and in any gathering, Hamze mourning was mentioned and this was traditionally common in the society.

At the night Imam Ali, the caliphate of Muslims and the first Imam of Shia people was martyred, the mourning voice was heard of his house. Kufe was all mourning and people moved to the house of Imam Ali as crying in the street.

After hearing the death of Hassan Ibn Ali, the second Imam of Shia people, Medina city was all mourning. The markets and shops were closed. People were mourning for seven days for Imam and they didn't open the markets. The women of Banihashem mourned for one month.

Gradually, this ritual became common as a tradition in the mourn for other Shia Imam and important people.

\section{Ashura}

History: It is the 10 Muharram in the year $61 \mathrm{AH}$ and in Shia culture, it is a day, the third Imam, the grandson of the Prophet (pbuh)-will all the family and followers older than 14 years in a location called Karbala, beside Forat River in Iraq were martyred in an unfair war by the caliphate (Yazid, the son of Moavie, the son of 
Abusofian) as they were accused of not accepting the non-democratic government being deviated from Islam and they didn't accepted the pledge. Their heads were cut and they bodies were cut into pieces and their wives and children were captivated. The followers of Imam Husayn in this war were 72, 19 of which were relatives of the Prophet. The most terrible tragedy was occurred about Imam Husayn with 33 spear wound and 34 sword wounds. After the martyrdom, they rode horses on his body without head. Yazid corps was 30 thousands.

The effect of Ashura on Islamic culture: Ashura is an event that is not comparable with any event in Islam world in terms of the importance and the outcomes and the results and there are some reasons:

1- The popularity of Imam Husayn before The Prophet (pbuh): The respect of the Prophet to two grandsons, Imam Husayn and Imam Hassan was proved by all Islamic religions. For example, the followings are proved by all Shia and Sunni books and the Prophet said:" I like Husayn and he likes me". Hassan and Husayn are the head of the youth in heaven". Historical evidences showed that the Prophet (pbuh) during the birth of Imam Husayn, the years before Ashura mourned for Karbala

2- Imam Husayn is one of the respectable people before the Muslims. Alaeli, the Sunni author said: There is no difference that Husayn was the selected and good man for all the tribes and different classes of people. People respected him and considered him with a superior view.

3- The terrible tragedy of the grandson of the Prophet and his followers caused loath to the Umayyad clan and the grief for the family of Imam Husayn.

4- The presence of the historians and messengers who considered Ashura directly and transferred with details to the people of the various Islamic cities (Kufe, Sham, Mecca and Medina) as the memory of this tragedy was in the culture of the Muslims namely Shia people.

5- The reaction of the Muslim community and Shia community to this event is important. The Shia people advertised and they didn't see any result of armed riot and Ashura became a tool for social motivation.

The bitter event affected the culture of the Muslims in Islamic countries and creates the poem and prose as Ashura writing and poems about Ashura. The main frame helping the crime of Umayyad on Ashura day and the stability of Husayn ibn Ali and the followers was the prose and poem. The poem indicating Imam Husayn riot and their martyrdom is called Resa.

After the martyrdom of Imam Husayn, he and his riot was the subject of Resa and elegy, mourning and poem and it is held in all over Shia realm in Moharam days and the second half of Safar considerably and during the months of the year. The subject of Resa besides emotional aspects covered political aspects and changed the poems of elegy poets to the poem with the aim of fighting against Banu- Umayyad caliphate and Banuabas and the cruel rulers.

Shia people all over the world mourned Imam Husayn to keep the event alive in the memory of all people and they applied some symbols and some of them are held over the time in the form of special rites in Moharam and Safar months.

The history of Ashura mourning: The activities of Shia people were manifested for the first time in 352 Qamari about three centuries after Ashura in Islam history. It means that as Alebuye dynasty took power (933-1056) in Baghdad, Moezoldole Deylami in Ashura ordered to mourn for Imam Husayn and the family of the Prophet and they closed the shops and 
cancelled selling and buy. The butchers didn't kill any animal and the cooks didn't cook. They set up some tents in the markets and palas (a kind of cloth) was hanging of it and the men were having black namad on their neck and they were knocking on their chest. Women with black clothes walked in the alley and market and mourned for Imam (pbuh). The historians said it was the first day they were mourning for the martyrs of Karbala as clearly.

By the collapse of Shia powerful dynasty, great restrictions were occurred but mourning was common among the Shia people and Sunni people were happy about this plan. Two famous people called Ali Ibn Husayn Qaznavi and Amir Ebadi as sunni people mourned for Imam Husayn. Ibn Juzi presented some of things from their mourning. Abdoljalil Razi in his book presents a full description of the mourning of sunni people in 6th century for the martyrs of Ashura and added:"Merasi, Neinava events common between Buhanife and Shafei followers is of outside number".

In 15th century, at Teimurian era (771$916 \mathrm{AH}$, Qamari), one of Sunni people wrote a book about the tragedy of the family of the Prophet and Ashura and developed mourning among Shia people. In Safavid era (1502-1735) that Shia religion was the formal religion of Iran, Ashura events was the center of the plans of Safavid kings and the importance of the great religious mourning was emphasized. Today, in Iran, Iraq, Lebanon, India, Pakistan and other countries, Shia people considered Ashura as the great religious mourning each year and they closed the shops and the people mourn and keep the memory of the great event.

\section{Ashura symbols}

Definition: In Ashura culture, the symbols are aroused of the deep beliefs with special meaning for a long time and had important role in calming the mourners and as a silent elegy expressed the message of Ashura in history.

Ashura symbols included all the tools and rites with the message for the mourners of the great riot and the followings are considered:

\section{Wearing dark}

In Moharam and Safar, mourning is held in all cities of Iran and some countries by different forms. Wearing black, gray and blue clothes is common. The holy shrines, mosques, Husaynie, markets and shops cover black and a black flag is above the houses and holy places. Some places as mosques, Husaynie are covered by black clothes with some poems of Mohtasham Kashani of Safavid era (1588) with Nastealiq writing is decorated.

\section{Mourning}

Other important aspect in Resa of Imam Husayn (pbuh) is Vaaz and Khatabe and after the martyrdom of Imam Husayn, they could make Shia people mourn for the martyrs. Empathy and group participation in sad event of the destiny of Imam Husayn was the important component of mourning. Saheb Ibn Ebad (358), the wise minister and Buyid poet had special interest in the propagation of mourning for Imam Husayn. He said some poems about the complementation of Imam being said during Ashura. Abubakr Kharazmi (935-993), the Iranian poet and wise man of 4 th century encouraged Shia people to respect the mourning of Imam Husayn. Besides Alebuye, Fatemian government (297-567) propagated mourning in Egypt. In 360 Qamari, Egyptian Shia people considered Ashura as grief time and mourned in their mourning ritu als. In the 
ministry of Afzal Ibn Badroljamal (10661121), the famous minister of Fatemian in Masjid Hoesseini of Cairo was prepared and the poets read the elegy for the memory of the martyrdom of Imam Husayn. After the descriptive citing of the sad event of Karbala was common. His student, Abolmoayid Movafaq Kharazmi (568) collected the religious stories of describing the virtues of the Prophet and his followers. He wrote an epic to describe the surrounding condition of the martyrdom of Imam Husayn and it is called Maqtal Kharazmi. Rozekhani term was created in the early Safavid era and it was common for the first time. Rozekhanan did the work of Madahan, elegy poets and Manaqebkhanan. Also they took the place of story tellers and Vaezan. Since then, Vaez and speech and elegy were collected among the Rozekhanan and they made the people cry by combining the prose and poem.

\section{Dirge}

Literally, dirge means mourning and lament and in literature, it is a poem for the newly dead person or Imam (pbuh). The most common form of Ashura poem is dirge. Dirge is a kind of elegy with special rhythm and the most common location is mourning rites namely mourning ritual of Imam Husayn. A person who says dirge is called Nohekhan or Nohesara. When the person starts dirge, Nohegaran knock on their chest and put chain on their shoulders and even use Qame. Dirge poems are considered as a part of popular literature and they have meter rhythm. But compared to other traditional forms of Persian poem in rhythm and rime, it is varied. Also, the equality of the verses in these religious poems is not important. Dirge is different from Ashura poem and it is its simplicity compared to great poems. Mostly, it has a part for repetition and
Tarji. Afail Oruzi is not complete in it and Bohur is mixed with it. The simplicity of dirge took it out of poem and its elements. Although now it is affected by its learning and some of the dirges are content based. The development of dirge was in Safavid era but before Qajarie era (1502-1735) there were no poem divans including the serious dirge.

As in Sabahi Bidgoli Divan (1218), there is an ode similar to dirge and some people considered it the first Persian dirge.

But the first poet that a part of his Divan is dedicated to dirge is Yaqma Jandaqi (1276). By some innovations in Ashura poem, such Ashura was formed. Later, Sorush Isfahani (1285) created two great works: Shast band that is read in the memory of Karbala martyrs.

Other people who created some works in this field were Abdoljavad Judi Khorasani (1302), Samet Borujerdi (12621331), Mirza Ebrahim Borujerdi (1340) and Tafreshi (1284-1344).

The relationship between dirge and music is more than Roze because dirge poems being said for mourning has specific rhythm being performed with the rhythm of some of Iranian song and it is similar to Tasnif. Dirge is a great factor to propagate our national music.

Mirza Taqikhan Amirkabir, the prime minister of Naseroldin Shah took special attention ot it and even some of the poets were made to say some poems for mourning.

Dirge in Pahlavi era (1925-1978) didn't develop anymore and it collapsed. The destruction of the rites was the result of the opposition of Reza Shah by holding these rites and his opposition to religion. He moved before the mourning group to take the attention of people and they had interesting display. He was disagree with 
dirge and creating mourning groups in the street.

After the victory of Islamic Revolution (Bahman 1978) and namely in Iran and Iraq war (1980-1988) dirge was developed again. This time, the origin of dirge- except the religious rites was war operation nights.

The most important aim of holding this type of rites was encouraging the war morale of the soldiers and empathy with Ashura martyrs among them. Some of the Nohesarayan considering their mission and the considerable effect of dirge among the people or the serious approach to value concepts developed the content of Ashurayi dirge.

\section{Coffin}

Shia people in the world namely Iranian Shia people move the decorated boxes in mourning groups on the anniversary of the martyrdom of religious martyrs and it is not coffin but it is a symbol of coffin and it is considered martyr coffin. The symbolic coffins are made as various forms and similar to tomb coffin, shrine and dome and have different names in various parts of Iran as Nakhl, Hejle, Shidune, Doqdoqe, Shesh Gushe, Nahr Alqame, and Shat Forat. Some of the coffins are dedicated only to a special part of Iran.

\section{Nakhl}

Moving Nakhl is one of the traditional rites of Iranian people namely desert geographical-cultural region as Yazd and some of the cities in Markazi province, Tehran and Khuzestan and it is a wooden and big instrument as rectangle cubic with a two slope or flat ceiling with two fronts with Jenagh form and nested with jugged sides.

\section{Hejle}

It is a chamber with various forms in most of Iran cities called Tehrani Hejle. It is made of wood and it is cylinder with some dome and flat ceilings and columns on a circular tray. The columns and around Hijle to under the ceiling was decorated by mirror and colorful papers or painting and colorful balls were hanging and candle, lantern and lamps were lit.

\section{Shidune}

It is a wooden chamber with rectangular cubic form simialr to shrine. The surface of the walls and columns are painted and covered by colorful, golden and silver things. Some verses are written about the martyrs on the band around Shidune.

Shidune is app lied in geographicalcultural field of Khuzestan namely in Dezful and Shushtar cities with Nakhl.

\section{Doghdoqe}

It is a flatbed being carried in Qom by the mourners of Imam Ali and Imam Husayn in Moharam. In the past, Doghdoghe was covered by black clothes and green Amame, sword and other war arms were applied.

\section{Sheshgushe}

A wooden box similar to hexagonal shrine of Imam Husayn. Its façade is colored and silver is applied in it. Some poems are written around it, under the ceiling, one the columns and some parts of Majar.

Sheshgushe is moved by the mourning group of Kashan on the 6th of Moharam called Sheshgushe.

\section{Alqame and Forat River}

Two chambers are decorated: One similar to shrine of Abas (pbuh) beside Alqame River (a branch of Forat River) and another one is simialr to the tent of Imam Husayn beside Forat River.

\section{Tazie (poems about the tragedy)}

214 | Page 
Among Iraqi Shia and India continent, the coffins similar to Imam Husayn shrine were called Tazieh.

\section{Imam Bare}

It is called "Imam Khane", Husaynie or Azakhane. Also, it is called the buildings in India that Shia people gather to hold special religious rites in Moharam.

For the first time, Navab Safdar Jang (1754), the ruler of Avade state in Delhi built a building to hold mourning rites in Moharam and it is called the first example of Imam Bare.

After building Imambare of Asefoldule (1784), the construction of Imambare was developed. It was common in mourning days to laminate Imambare as Shushtari (1805) said:" Imambare of Asefoldule was decorated with candle, lamp, mirrors and gold.

\section{Tashtgardani}

Other traditional rites in some cities in Iran including Ardebil are "Tashtgardani". Water tubs were brought in the mosques and Husaynie and it was the symbol of Forat. The symbols indicating the special place including water tasht and some plant stems as the symbol of river and Nakhlestan showed that in Ashura Tazie, using symbols was common. Three days to Moharam in Masjid Jame, Masjid Azam and other mosques, some Tashts were on their heads and they were walking around the mosque and they were pouring water into it. The people were putting their hand into it and it was a kind of pledge with Imam Husayn (pbuh) and supporting Abas (phuh).

\section{Carrying Alam, Kotal, Beiraq, Panje and Tuq}

For mourning group, each township had the special symbol or flag different from other flags and the people were following it and they were mourning.

\section{Alam}

It is a flag being carried in religious rites and it is a part of clothe decorated with a special color and symbol hung by a bar.

Ibn Khaldun considered the history of using science to the beginning of creation . It is said: The history is followed to $\mathbf{5 0 0 0}$ years ago". In Karbala battlefield, Abas (pbuh) was carrying the flag of the corps of Imam Husain. One of the slogans of Iraqi Arabs is including:" " رَفَعَ اللهُ رايَةَ العَبَاس": The flag of Abas (pbuh) should be raised always.

Alam: At first the flags were tall but at the end of Safavid era, the flags were shorter and wider as the current flags got more common. The symbols were considered the mourning group and the people who carried them were taking the flag.

According to Dehkhoda It is a cross on which Terme scarves are hung on its wood or horizontal iron and some statues in the form of hen were installed and they were between long metal and a ball of colorful glass was on it and the metals called "bladder" were 3 or 5 and they were carried in mourning group. In Naseroldin Shah era, the government Alam was called royal Alam and it was carried magnificently. The Rozekhans had special flag.

\section{Kotal}

It is a big Alam being carried in mourning groups and it is the Alam its upper part is covered by sleeveless shirt.

\section{Panje}

The symbol of hand from the fist to the head of five fingers being made of copper, brass, Varshu, silver and gold and they put it on the paper, clothe and other things and they apply as the power, respect and charm.

Shia people considered it as the symbol of five Al-Aba or a symbol of the cut hand 
of Abas (pbuh) and the Muslims of the south of India considered it as a symbol of the hand of Imam Ali, Fateme (pbuh) and Abas Alamdar. The Muslim Indians decorate a Panje on the first, second, third and fourth days of Moharam as decorating the "Ahurakhane" and they put it beside Alam and visit it. In other Islamic countries, this symbol exists in mourning groups. In Qajar era, the third day of Moharam in Naseredinshah, an Alam called Alam Shah-a big panje was built on its head made of gold-it was brought into inside and the women in the court were mourning beside it. Then, a group moved Alam Shah and moved it to Tekye Do lat and mourning rites was performed beside it.

\section{Tugh}

It means Alam and symbol and decorative things of mourning groups and it is a base on which a box is located and a tall metal is on the box and a scarf is on the tip of metal and a person carries it. In the past, a bob of horse tail or silk was on the bar instead of the flag and it was used to determine the location of gathering of corps.

\section{Tabutgardani}

Carrying symbolic coffin for symbolic burial of the martyrs in mourning rites is called Tabutgardani.

The history in ancient Iran: According to historical narrations, the people from Transoxiana from the old times to the early centuries of Islamic period, for the anniversary of the death of Siavash, the Iranian hero built his statue and put it in a box and they were moving as mourning.

In Islamic Iran: According to the reports of the early 5th century $\mathrm{AH}$, Gorkh of Baghdad as visiting the shrine of Imam Ali and Imam Husayn, some instruments called Manjeniq were decorated with gold.

Manjeniq was the first and oldest religious slogan and a symbol of coffin or the shrine of the first and third Imam of Shia people.

In recent centuries, in mourning for Imam Husayn, a coffin was carried out in mourning groups as the symbol of martyrs of Karbala. In central regions of Iran, Yazd, Nayin, Kashan, Tabriz and some of desert villages had Tabutgardani ritual.

Sinezani (hitting the chest), Zanjirzani (hitting with chain) and Qamezani (cutting the forehead)

Sinezani: It is one of traditional mourning rituals for Imam Husayn and the family and they hit their chest with Nuha. Marching, Sinezani and Nuha were common in Safavid era. In Qajar era, it was more common by the development in the capital. Marching in Qajar era namely in Naserodinshah era was held with more rituals. The marching was done by new music and Alam, flag and Kotal and night marching with lantern and Hijle and flames and they were hitting their chest with rhythmic sound.

Zanjirzani: It is one of the mourning traditions in Iran. This method was common in Pakistan and India for a long time. A set of small rings attached to each other to a wooden or metal handle is called "chain (zanjir) and it is applied in Ashura as marching in mourning with Nuha and sometimes it hit the person. This ritual is held sometimes with Senj.

This mourning method is with the blood coming out of the back of Zanjirzanan namely in some regions, they were using a chain with blades. As it was violent for some non-Muslims, some of the Muslim scholars prohibited it.

Qamezani: The rituals in which some of Shia people perform for mourning Imam Husayn and it is done as the symbol of sacrifice before Imam Husayn and Karbala martyrs.

Early in the morning of Ashura, they wore a tall white attire as Kafan in a group and 
they were cutting there forehead with knife and the blood was flowing from their head and face. Some of them were giving pledge for Qamezani. Some of them did such pledge for small children and used hit them by blade to flow the blood.

Qamezani like Zanjirzani and Shabihkhani was different among the Islamic scholars and their followers and they allowed or didn't allow it. This ritual is not religious act.

Shurzadan: It is a term of mourning. When during mourning, a person is at the peak of emotions, the rhythm of his movements and voices get quicker and louder.

Drum and Senj

Drum: It is the general term of each of various music instruments with a tubular body (cone or cylinder) with skin on the body and it is played by hand or some wooden bars. It is mostly used to make voice and it played in mourning march with Sinezani and Zanjirzani.

Senj: It is an instrument as a pair of copper, brass or silver plane with some handles in the external part and it is used in mourning march with retelling Nuha.

\section{The Critique of Ashura Symbols}

Ashura event indicates courage, sacrifice of Imam Husayn (pbuh) and his followers and it was recognized as freedom ritual and the fight against cruelty and the people in this event were considered as the role model of others because their goal was showing the peak of human being ideals. The ideals being accepted by all human being including sacrifice, belief stability and faith, pledge, purification, justice and other human values.

Although Ashura symbols can be the best was to express empathy with the family of the Prophet in history, but formal and content distortion, falsification, extremes, superstition, common people deceiving, distortion of the facts, wasting the times and properties and unsuitable displays in mourning rituals and the emptiness of Ashura of excellent goals provide the ground that Alebuye, Safavid and Qajar and other dictators by the superstition paved the way for mourning of Ashura and crying for Imam Husayn, family and friends. They gathered and mourned for their Imam who preferred martyrdom to continuing life due to fighting against cruelty.

By being far from the existing condition of mourning for Imam Husayn, some negative dimensions were created and by deepening the distances, the negative aspects got more and more. The good condition was the recommendations, goals and performances of the family of Prophet to respect the movement.

\section{The negative aspects are including:}

Extreme acts to use some Ashura symbols as Zanjirzani and Qamezani hurting the body.

Simulating and false Tazie as Qasem marriage Tazie and Do Teflan Moslem didn't have any historical documents.

Replacing bizarre voices instead of effective Nuha music. Unusual narrations by people without any good voice or elegy taste in contemporary Nuha and it made the ritual problematic.

Showing the great soul of Imam Husayn as a person who cannot resist the thirst or he wishes his son become groom.

Using illiterate people to say the elegy and Rouze to show a distorted view of the heroes of the proud movement only to make the people cry on their thirst or the oppression of their enemies.

Showing an unwise view of the crying by hitting the head and chest and throwing soil and mud on the head.

Using the symbols of other religions as using Alam in religious marching. 


\section{Some Solutions to Remove the Negative Aspects}

It is said that the good condition is the goals and methods of Ashura about the family of the Prophet for the respect of the event. Thus, presenting any solution should be dependent upon the goals and methods as following:

Recognizing the goals of Imam Husayn about the movement as resistance against oppression and Islam distortion from the initial principles.

Respecting the martyrs of the battle by moment by moment expression of the events on Ashura day.

Making Ashura culture public by encouraging people for crying and its constant remembrance even during drinking water.

Encouraging the poets to say the epic poems for Karbala martyrs.

\section{To achieve the above goals, the followings should be done:}

To mention Ashura event, valid sources without any superstition should be mentioned.

By showing opposite religious acts as Qamezani and any rituals leading into body hurt, an advertising fighting should be based.

Encouraging the poets to present sad poems with epic meaning in accordance with Ashura movement.

Using goodlooking Madahan with good voice and making them familiar with the goals and philosophy of Ashura by presenting correct and documented Roze.

Separating the false and exaggerative Nuha and presenting the text of correct Tazie in accordance with the realities.

\section{Summary and Conclusion}

Since Ashura, commemoration for Imam Husayn is held in any region as specifically and various nations had some effects in holding it. Muslims of any country in accordance with their beliefs created some various methods for this ritual and they applied specific symbols. In the history, Ashura event in any region is new and Ashura symbols had special concepts.

The false methods of some of the mourners namely they were not in Ashura blood and riot, caused that human being assumes that there are some politicians who abuse the love of people and they try to change their rituals to ignore the excellent goals of Imam Husayn among the preparation for mourning.

It seems by false interpretation of this sad event, the message of Imam Husayn is forgotten and some meanings of the philosophy of fighting against oppression and its belief of deep principles are not recognized.

All the superstitions, common people deceive, distortion of the facts, wasting the time and property, changing the minds and unsuitable display in some mourning rituals caused that we ignore what we do and in what time and place we are in. How the spiritual benefits of Ashura with the legacy of Shia people should be used? How we can follow the new methods of Al-Buye rulers and Safavid kings and make them alive? Or by simulating, Tazie, Nuha, hitting the head and throwing he soil and mud, Qamezani, make an unwise view of crying and ignore the courage, bravery, sacrifice and the speech of Imam to cry for water or wishing his son marry? Or we search for Ashura philosophy in the message of Imam and reform each word speech and apply freedom rituals and fighting against oppression in coping with 
oppression as Imams? Why we should use superstitions to introduce the humanity of good people? Is it true to direct the excellent goals of Ashura martyrs from the great human ideals to the false facts? Is it true to mention Zeinab (pbhuh), Imam Sajad, Moslem Ibn Aqil, Sakine, etc in the Rouze, Tazieh and the poems and Nuha as opposite to their noble family? In this case, the mission of helping Ashura movement during the history, it is only limited to crying on the thirst and the tragedy and before thinking about his goal, the wounded body of Imam Husayn and his cut throat comes to the mind? It seems that the fight of the enemies with the principle of mourning for Imam Husayn is changed into the freedom of the rituals and propagation of the slogans but by distorting the fact of Ashura and Karbala philosophy, the plans are not contradictory with the dominance of oppression of cruel rulers and this is the greatest content distortion of Ashura. The historical evidence in this regard is Tavabin riot being formed after the crying over the tomb of Karbala martyrs for the remembrance of Imam Husayn and Shia people in Karbala being inspired of Ashura with the leadership of Soleiman Ibn Sorad Khozai organized a movement. Thus, Ashura really and by the witness of history was inspiring for every Muslim.

If fighting against oppression is one of the achievements of movement of Ashura for future generation, respecting Ashura ritual promotes oppression fight morale and it is disliked by cruel rulers. The opposite result of this process is including: If a cruel ruler is present in Ashura ritual or prepare it, such ritual is not contradictory with its behavior method of the cruel ruler. When a cruel ruler as Shah Abbas Safavid held mourning ritual and participated in marching and a dictator as Naseredin Shah didn't consider any contradiction between cruel methods of his government and providing the best facilities for holding Tazie or mourning ritual in the second Pahlavi time in Moharam and they were mourning, the doubts about the content distortion of Ashura was ignored. In other words, in Ashura of $61 \mathrm{AH}$, there was cruelty was done on Imam Husayn and in thousands of Ashura over the time on the goals of Imam Husayn.

Another distortion aspect is formal distortions in Ashura ritual. For example, Nuha is an old art being permanent in the heart of people with good voice and it has special position as including a part of Iran music but the current generation ignored the elegy songs for Karbala martyrs. The major part that is common in the form of Nuha among the zanjirzani and Sinezani marching, unusual rhythms are heard with no relation with good music of Nuha and Nuhasarayan of this country.

Unusual innovations presented by the people with no good voice and no elegy taste, in contemporary Nuha made great legacy of some centuries problematic.

It seems that true determination of Ashura movement, presenting correct and documented Rouze, preventing to read false elegy and incorrect Marsiekhanan and illiterate Madahan are recommended as some solutions to cope with the distortion.

If the poets by long and full poems and free of any superstition and preventing the sadness but with the epic with fighting with oppression respected the rituals and they can take an effective step to remove the distortion.

By comparative investigation of the behavior of the families of the martyrs of 
Ashura and the performance of Ahl-eBeit to remember the historical sad event and the methods of the rulers since AleBuye dynasty and then in Safavid era and in contemporary governments was evaluated as scientifically that by renovation of good traditions, some of the bad traditions are reduced. In this case we will have a deep understanding of Ashura with the message to all human being as a great human duty and Islamic event. An everlasting message, "Honorable martyrdom not disgraceful life".

\section{References}

Abolfazli, Mohammad, Mourning rituals of Moharam in Kashan (the articles of the first conference of anthropology of cultural heritage organization). Tehran. 1992.

Al-Alaeli, Abdollah. Al-Imam Husayn. Beirut: Dar Maktabe Al-Tarbie. 1972.

Amini, Abdolhossein, Al-Qadir Fi Ketab va Al-Sonat va Al-Adab. Qom: Dar olkotob Al-Eslamie. 1995-2000.

Belazari, Ahmad Ibn Yahya, Ensab AlAshraf. Tahqiq Zarkar.

Blukbashi, Ali, Nakhlgardani. Tehran. 2001.

Daneshname Sher Ashurayi, Mohammadzade, Marzie, Tehran: The publication organization of Islamic guidance and culture. 2004.

Dehkhoda, Ali Akbar. Dictionary under the supervision of Dr. Mohammad Moein and Dr. Seyed Jafar Shahidi, Tehran. 1998.

Dehlavi, Ahmad. Asefie dictionary. Delhi. 1974.
Doerfer 'G. Turkische und mongolische Elemente im Neupersis Chen 'Wiesbaden 1963- 1975.

Farhang, Mohammad Hossein, Sociology and anthropology of Afghanistan Shia. Qom. 2001.

Faqihi, Ali Asqar. Religious history: Jame history of Qom. Qom: Hekmat.

Hakem Neishaburi, Mohammad Ibn Abdollah. Mostadrak Ala Sahihin, Halab of Syria: Maktabat Al-Matbuat AlEslamie.

Hollister ،J. $\mathrm{N}$ ،The Shia of India ‘New Delhi 1979.

Ibn Abi Al-Hadid, Ezoldin Abdolhammid Ibn Mohammad, Nahjolbalaqe description of Ibn Abi Al-Hadid, Tahqiq Mohammad Abolfazl Ibrahim, Cairo: 1965-1967.

Ibn Asir, Ezoldin Ali Ibn Ahmad Ibn Abi Akram, Asad Al-Qabe Fi Marefat AlSahabe, Tahqiq Adel Ahmad Refai, Beirut: 1966.

Ibn Asir, Ezoldin Ali Ibn Ahmad Ibn Abi Al-Karam, Al-Kamel Fi-Al-Tarikh, Ibn Asir, Ezoldin Ali Ibn Ahmad Ibn Abi AlKaram, Tahqiq Maktabat Al-Toras, Beirut: 2006-2007.

Ibn Asam Kufi, Al-Fotuh, Heidar Abad Dekan: 1975.

Ibn Batute, Rehle Ibn Batute.

Ibn Juzi, Abolrahman, Al-Montazam Fi Tarikh Al-Omam va Al-Moluk, Heidar Abad Dekan:1359 Ghamari.

Ibn Khaldun, Abdolrahman, Tarikh Ibn Khaldun (Al-Ebr va Divan Al-Mobtada va Al-Khabar). Translated by Mohammad Parvin Gonabadi, Tehran: Scientific and culture publications. 1991. 
Ibn Saad, Al-Tabaqat Al-Kobra, Tahqiq Ehsan Abas, Beirut: 1985.

Ibn Abdrie, Ahmad Ibn Mahmood, Al-Aqd Al-Farid, attempted by Ahmad Amin et al., Cairo: 1973.

Ibn Kasir Dameshqi, Emad Al-Din Ismail Ibn Omar, El-Bedayat va AlNahayat:1932.

Ibn Maje, Sonan Ibn Maje, published by Mohammad Foad Abdolbaqi, Cairo: 1954. Offset publication. Beirut.

Ibn Hashem, Mohammad Ibn Abdolmalek, Al-Sirat Al-nabavie, Tahqiq Mostafa Al-Saqa et al. Qom. Iran publications. 1984.

Jaffri ‘H. A “"Muharram Ceremonies in India" Taziyeh Ritual and Drama in Iran ، New York / Tehran ‘1979.

Kharazmi, Hossein. Maqtal Al-Hossein Kharazmi, attempted by Al-Sheikh Mohammad Samavi. Najaf: Matbae AlZahra. 1988 Ghamari.

Khatib Baqdadi, Abubakr Ahmad Ibn Ali. Baghdad history. Beirut: Darolkotob Arabi.

Kheyrandish, Rasul. Reasons of the name and the flag of the countries. Tehran. 1991.

Mashhun, Hassan, Iranian religious Music. Art celebrity organization. 1971.

Masaheb, Qolamhossein, Persian encyclopedia, Tehran. Amirkabir publication. 2004.

Masoodi, Ali Ibn Al- Husayn, Moravej AlZahb and Maaden Al-Johar. Tahqiq Barbie Domenar and Pave Dokurti, Paris. 1861-1877.
Moayerolmamalek, Dustali, The notes of the private life of Naseroldinshah. Tehran. 1972.

Mofid, Mohammad Ibn Mohammad Ibn Naman, Ershad. Translated by Sheikh Mohammad Baqer Saedi Khorasani, Tehran. Eslamie book store. 1972.

Moein, Dr. Mohammad. Persian dictionary. Tehran: Amirkabir publication. 1999.

Rituals in Ferdosi Shahname.

Shabani, Aziz. The identification of Iranian music. 1973.

Sharif. J. 'Islam in India. Herklots. ‘ tr.G.A. London. 1975.

Sharif. J. 'Islam in India. Herklots. ‘ tr.G.A. London. 1975.

Shahrestani, Saleh, Imam Husayn mourning since Adam to the present. Tehran: 1393 Ghamari.

Sharif Yusef. Tarikh Fan Al-Emare AlAraqie Fi Mokhtalef Al-Osur. Baghdad. 1982.

Shushtari, Qazi Nurollah, Majalis AlMoemenin. Tehran: Islamie library publication. 1998.

Tabari, Mohammad Ibn Jarir. Tarikh AlOmam va Al-Moluk (Tabari history). Mohammad Abolfazl Ebrahim pu blication. Beirut. Mohammad Abolfazl Ebrahim publication. 1962-1967.

Termazi, Mohammad Ibn Isa. Sonan Termazi (Al-Jame Al-Sahih), published by Abdolvahab Abdollatif. Beirut. 1983.

They Holy Quran

Tusi, Mohammad Ibn Hassan. Tahzib AlAhkam, Hassan Musavi Khorsan publication. Beirut. 1981. 
Vaez Khargushi, Abu Saeed, Sharf AlNabi, Translated by Dr. Mohammud Mahdavi Damqani. Tehran. Nashr Ney. 2004.

Vaqedi, Mohammad Ibn Omar, Al-Maqazi, Tahqiq Marsden Jons. Qom: Islamic knowledge publication. 1405 Ghamari.
Yafei, Abdollah Ibn Asad. Merat Al-Jenan va Ebrat Al-Yaqzan $\mathrm{Fi}$ Marefat $\mathrm{Ma}$ Yatabar Men Havades Al-Zaman. Egypt: Dar Ketab Islamic. 1413.

Yaqut Hamavi, Shahab Al-Din Abi Abdollah, Moajam Al-Boldan, Beirut: Dar Ehya Al-Toras Al-arabi. 1399 Qamari.

How to cite this article: Marziyeh Mohammadzadeh, The Structural Analysis of Symbols in the Ashurayi Literature. International Journal of Advanced Studies in Humanities and Social Science, 2019, 8(2), 209-222. http://www.ijashssjournal.com/article 84361.html 